\title{
PENGARUH MODEL PEMBELAJARAN QUANTUM TEACHING TIPE TANDUR DIINTEGRASIKAN DENGAN KARTU TANGRAM TERHADAP HASIL BELAJAR MATEMATIKA SISWA
}

\author{
Annisa Laras Khairani ${ }^{1)}$, dkk dan Ismah ${ }^{2)}$ \\ Universitas Muhammadiyah Jakarta \\ 1)khairanizain@yahoo.com \\ 2) ismah.fr@gmail.com
}

\begin{abstract}
Abstrak
Penelitian ini bertujuan untuk mengetahui pengaruh model pembelajaran Quantum Teaching tipe TANDUR diintegrasikan dengan kartu tangram terhadap hasil belajar matematika siswa. Metode penelitian ini adalah Quasi Eksperimen dengan design penelitian yaitu Posttest-Only Control Design. Populasi pada penelitian ini adalah seluruh siswa kelas 7 SMPIT Ulil Albab dengan sampel sebanyak 2 kelas (kelas 7 Ali dan kelas 7 Shaffiyah), pengambilan ini dilakukan dengan teknik purposive sampling dan simple random sampling. Instrumen yang digunakan dalam pengumpulan data adalah tes dan wawancara, uji hipotesis menggunakan rumus uji-t. Berdasarkan perhitungan uji-t diperoleh $\mathrm{t}_{\text {hitung }}=5,54$ lebih besar daripada $\mathrm{t}_{\text {tabel }}(\mathrm{dk}=52$ pada taraf signifikan 0,05$)=1,67$, artinya terdapat pengaruh model pembelajaran Quantum Teaching tipe TANDUR diintegrasikan dengan kartu tangram terhadap hasil belajar matematika siswa. Selain itu dari analisis data diperoleh peningkatan hasil belajar matematika siswa setelah menggunakan model pembelajaran Quantum Teaching tipe TANDUR diintegrasikan dengan kartu tangram, dilihat dari rata-rata skor tes pada kelas eksperimen yaitu 76,96 dan pada kelas kontrol yaitu 64,73. Dari kesimpulan wawancara, siswa merasa senang dengan pembelajaran tersebut karena tidak menjenuhkan dan dengan mudah dapat mengerti dan memahami materi.
\end{abstract}

Kata kunci: Model Pembelajaran Quantum Teaching tipe TANDUR, Kartu Tangram, Hasil Belajar Matematika

\section{PENDAHULUAN}

Pada saat ini para ahli dan pemerhati pendidikan secara intensif mencurahkan perhatiannya dalam upaya mengembangkan konsep keberbakatan, yang diyakini terbentuk dari tiga komponen, yaitu: keunggulan intelektual, keterikatan pada tugas (motivasi), dan 
kreativitas. Hal tersebut perlu dimanifestasikan dalam setiap mata pelajaran di sekolah, termasuk matematika.

Dalam standar isi untuk satuan pendidikan dasar dan menengah mata pelajaran matematika (Peraturan Menteri Pendidikan Nasional Nomor 22 Tahun 2006 tanggal 23 Mei 2006 tentang standar isi) telah disebutkan bahwa mata pelajaran matematika perlu diberikan kepada semua peserta didik mulai dari sekolah dasar untuk membekali peserta didik dengan kemampuan berpikir logis, analitis, sistematis, kritis, dan kreatif, serta kemampuan bekerja sama. Mengembangkan kemampuan berpikir logis, analitis, sistematis, kritis maupun bekerja sama sudah lama menjadi fokus dan perhatian pendidik matematika di kelas, karena hal itu berkaitan dengan sifat dan karakteristik keilmuan matematika.

Dalam pembelajaran matematika kreativitas siswa sangat dibutuhkan terutama dalam menyelesaikan soal-soal yang melibatkan siswa untuk berpikir kreatif, dimana siswa diharapkan dapat mengemukakan ide-ide baru yang kreatif dalam menganalisis dan menyelesaikan soal. Pola pembelajaran matematika masih kental dengan teacher centre yakni guru masih mendominasi sebagai pemberi informasi sehingga kemampuan siswa untuk memahami materi relatif rendah dan membuat siswa juga menjadi pasif. Proses pembelajaran tersebut hanya diarahkan kepada kemampuan siswa untuk menghafal informasi, otak anak dipaksa untuk mengingat dan menimbun berbagai informasi tanpa dituntut untuk memahami informasi yang diingatnya dan menghubungkannya dengan kehidupan sehari-hari. Guru memberikan contoh soal dilanjutkan memberikan latihan soal yang sifatnya rutin dan kurang melatih daya nalar, sehingga mengakibatkan kegiatan pembelajaran yang membosankan bagi siswa. Sebagian besar siswa menganggap pelajaran matematika adalah pelajaran yang sulit. Karena terlalu banyak rumus-rumus dan perhitungan.

Perlu diketahui bahwa pendidikan kemarin, sekarang dan yang akan datang banyak perubahan. Guru yang selalu menggunakan metode monoton, artinya dari tahun ke tahun tidak pernah mengalami perubahan karena adanya perubahan kondisi, mereka akan mengalami permasalahan yang tidak mereka sadari.

Oleh karena itu sebagai seorang pendidik perlu tahu mengenai kebutuhan anak didik, terutama dalam pelayanan dan penyampaian materi pelajaran. Sehingga sangat perlulah sebagai pendidik mengadakan variasi metode pengajarannya manakah yang lebih tepat untuk menyampaikan materi supaya hasil proses belajar mengajar berhasil maksimal. Perubahan pengajaran tidak harus disertai dengan pemakaian sarana dan prasarana yang bagus tetapi lebih menekankan pada pengembangan cara-cara baru belajar yang lebih efektif dan sesuai dengan kemampuan peserta didik. 
Pembelajaran akan efektif bila guru dapat mengidentifikasi masalah yang dihadapi di kelasnya, kemudian menganalisa dan menentukan faktor-faktor yang diduga menjadi penyebab utama, yang selanjutnya menentukan tindakan pemecahannya. Tuntutan peningkatan kualitas profesional guru belum memenuhi syarat yang diinginkan atau diharapkan, karena antara petunjuk perlaksanaan yang sudah ada banyak terdapat kendala bagi para pelaksana pendidikan utamanya guru terbukti dengan dampak yang dilapangan antara lain : (1) Kreativitas anak didik masih sangat rendah, terutama tentang pemahaman bangun datar, (2) Tingkat pengetahuan dan prestasi siswa dalam mata pelajaran matematika lebih rendah dari mata pelajaran yang lain, (3) Suasana belajar kurang dinamis.

Permasalahan di atas disebabkan oleh dominasi guru masih tinggi, peran guru dalam proses belajar mengajar sebagai penyebar ilmu kurang berperan sebagai fasilitator, guru masih banyak bergantung pada buku, guru masih dominan menggunakan ceramah dan mencatat, guru kurang mengoptimalkan bekerja bersama-sama dan siswa dianggap lulus tes atau dapat mengerjakan tes tanpa memperhatikan aspek lain seperti kejujuran, pengendalian diri, penghargaan kepada orang lain, dan kemampuan bekerja sama. Demikian gambaran situasi pembelajaran saat ini yang terjadi di lapangan khususnya pembelajaran di Sekolah Menengah Pertama. Kualitas pembelajaran dapat dilihat dari segi proses pembelajaran bukan dari segi hasil.

Dari segi proses pembelajaran dikatakan berhasil apabila seluruhnya atau setidaktidaknya sebagian besar (75\%) peserta didik terlibat secara aktif baik fisik, mental maupun sosial dalam proses pembelajaran di samping menunjukkan kegairahan belajar tinggi, semangat belajar yang besar dan rasa percaya diri yang tinggi. Sedangkan dari segi hasil proses pembelajaran dikatakan berhasil apabila terjadi perubahan prilaku yang positif dari peserta didik seluruhnya. Dalam penggunaan metode belajar mengajar banyak sekali jenisnya, hal ini dikarenakan metode-metode tersebut dipengaruhi oleh beberapa faktor diantaranya : tujuan dan fungsinya, tingkat kematangan siswa yang berbeda, situasi dan keadaan, pribadi guru dan kemampuan profesional yang berbeda-beda. Karena itu sulit untuk memberikan satu klasifikasi yang jelas mengenai metode yang ada di dalam pengajaran. Pada kenyataannya banyak faktor yang menyebabkan tidak selalu dapat dipergunakannya metode tersebut.

Guru sering kali menggunakan metode ceramah agar pembelajaran bisa diterima tetapi berdasarkan hasil ulangan harian ke 2 mata pelajaran matematika di SMPIT Ulil Albab dengan kompetensi dasar "Mengidentifikasi sifat-sifat persegi panjang, persegi, trapesium, jajargenjang, belah ketupat dan layang-layang", menunjukkan rendahnya tingkat penguasaan 
materi. Dari 30 siswa di kelas hanya 11 siswa yang mencapai tingkat penguasaaan materi sebesar 75\% ke atas. Oleh karena itu, peneliti meminta bantuan kepada teman sejawat untuk mengidentifikasi kekurangan dalam pembelajaran.

Dari hasil diskusi tersebut, maka terungkap masalah yang terjadi dalam pembelajaran, yaitu "Rendahnya tingkat penguasaan siswa terhadap materi". Setelah penulis menganalisa dengan melakukan diskusi dan tukar pendapat dengan teman sejawat selaku pengamat, maka diketahui bahwa faktor penyebab siswa kurang menguasai materi yang diajarkan adalah : (1) Kurangnya kreativitas siswa dalam memahami materi bangun datar, (2) Guru dalam menjelaskan materi terlalu cepat, dan (3) Model pembelajaran yang membuat siswa bosan.

Bertitik tolak dari penjelasan diatas, hasil belajar siswa sangat penting untuk ditingkatkan di dalam proses belajar mengajar, terutama dalam menguasai materi pelajaran. Matematika merupakan mata pelajaran yang menuntut siswa perlu memilki rasa ingin tahu dalam memecahkan suatu masalah. Guru selaku pembimbing perlu menerapkan model pembelajaran yang tepat bagi siswa yang ditunjang dengan media pembelajaran dalam meningkatkan hasil belajar siswa tersebut. Untuk meningkatkan hasil belajar siswa tersebut maka model pembelajaran yang tepat adalah dengan menggunakan model Quantum Teaching tipe TANDUR yang diintegrasikan dengan kartu tangram.

Penelitian Asrini (2010) membuktikan bahwa Quantum Teaching tipe TANDUR dapat meningkatkan hasil belajar kognitif siswa MAN 2 Kebumen. Hal ini sejalan dengan penelitian Tanjung \& Afriyani (2012) dan Pratiwi et al (2013) bahwa, terdapat peningkatan hasil belajar belajar siswa selama proses pembelajaran dengan menggunakan model Quantum Teaching. Oleh karena itu, model pembelajaran ini perlu dilaksanakan di SMPIT Ulil Albab pada materi bangun datar. Dengan model pembelajaran Quantum Teaching tipe TANDUR diharapkan dapat meningkatkan hasil belajar matematika siswa.

Dalam penelitian ini dirumuskan permasalahannya sebagai berikut : (1) Bagaimana tanggapan siswa mengenai penerapan model pembelajaran Quantum Teaching tipe TANDUR diintegrasikan dengan kartu tangram terhadap hasil belajar matematika ?, (2) Apakah hasil belajar matematika siswa lebih tinggi dengan menggunakan model pembelajaran Quantum Teaching tipe TANDUR diintegrasikan dengan kartu tangram dibandingkan dengan tidak menggunakan model pembelajaran Quantum Teaching tipe TANDUR diintegrasikan dengan kartu tangram ?.

Penelitian ini bertujuan untuk : (1) Mengetahui tanggapan siswa mengenai penerapan model pembelajaran Quantum Teaching tipe TANDUR diintegrasikan dengan kartu tangram terhadap hasil belajar matematika, (2) Mengetahui hasil belajar matematika siswa lebih tinggi 
dengan menggunakan model pembelajaran Quantum Teaching tipe TANDUR diintegrasikan dengan kartu tangram dibandingkan dengan tidak menggunakan model pembelajaran Quantum Teaching tipe TANDUR diintegrasikan dengan kartu tangram.

\section{KAJIAN PUSTAKA}

Matematika merupakan salah satu disiplin ilmu yang dapat meningkatkan kemampuan berpikir dan berargumentasi, memberikan kontribusi dalam penyelesaian masalah sehari-hari dan dalam dunia kerja, serta memberikan dukungan dalam pengembangan ilmu pengetahuan dan teknologi. Kebutuhan akan aplikasi matematika saat ini dan masa depan tidak hanya untuk keperluan sehari-hari, tetapi terutama dalam dunia kerja, dan untuk mendukung perkembangan ilmu pengetahuan. Oleh karena itu, matematika sebagai ilmu dasar perlu dikuasai dengan baik oleh siswa, terutama sejak usia sekolah dasar (Susanto, 2013: 185).

Hamalik (dalam Susanto 2013: 3) menjelaskan bahwa belajar adalah memodifikasi atau memperteguh perilaku melalui pengalaman (learning is defined as the modificator or strengthening of behavior through experiencing). Menurut pengertian ini, belajar merupakan suatu proses, suatu kegiatan, dan bukan merupakan suatu hasil atau tujuan. Dengan demikian, belajar itu bukan sekadar mengingat atau menghafal saja, namun lebih luas dari itu merupakan mengalami. Hamalik juga menegaskan bahwa belajar adalah suatu proses perubahan tingkah laku individu atau seseorang melalui interaksi dengan lingkungannya. Perubahan tingkah laku ini mencakup perubahan dalam kebiasaan (habit), sikap (afektif), dan keterampilan (psikomotorik). Perubahan tingkah laku dalam kegiatan belajar disebabkan oleh pengalaman atau latihan.

Secara sederhana, yang dimaksud dengan hasil belajar siswa adalah kemampuan yang diperoleh anakl setelah melalui kegiatan belajar. Karena belajar itu sendiri merupakan suatu proses dari seseorang yang berusaha untuk memperoleh suatu bentuk perubahan perilaku yang relatif menetap. Dalam kegiatan pembelajaran atau kegiatan instruksional, biasanya guru menetapkan tujuan belajar. Anak yang berhasil dalam belajar adalah yang berhasil mencapai tujuan-tujuan pembelajaran atau tujuan instruksional (Susanto, 2013: 5).

Quantum Teaching adalah orkestrasi bermacam-macam interaksi yang ada di dalam dan di sekitar momen belajar. Interaksi-interaksi ini mencakup unsur-unsur untuk belajar efektif yang mempengaruhi kesuksesan siswa. Interaksi-interaksi ini mengubah kemampuan dan bakat alamiah siswa menjadi cahaya yang akan bermanfaat bagi mereka sendiri dan orang lain (DePorter, 2014: 34). 
Bobby DePorter (dalam Kosasih 2013: 89), mengembangkan strategi pembelajaran Quantum Teaching melalui istilah TANDUR, yaitu Tumbuhkan, Alami, Namai, Demonstrasikan, Ulangi dan Rayakan.

Menurut Sobel (2002: 156) "Satu di antara permainan yang paling tua yang dikenal dalam matematika adalah permainan orang Cina kuno yang dinamakan tangram”. Tangram berasal dari kata Tang dan Gram. Tangram (Bahasa Mandarin : 七巧板 (qīi qiăo băn), secara harafiah berarti "tujuh papan keterampilan" adalah suatu puzzle yang terdiri dari tujuh keping bangun datar (disebut 'tans') yang terdiri atas :

1) Dua segitiga siku-siku sama kaki (besar)

2) Dua segitiga siku-siku sama kaki (kecil)

3) Satu segitiga siku-siku sama kaki (sedang)

4) Satu bujursangkar (kecil), dan

5) Satu jajaran genjang

\section{METODE PENELITIAN}

Penelitian ini dilaksanakan di SMPIT Ulil Albab Kecamatan Cibitung Kabupaten Bekasi. Waktu penelitian ini dilaksanakan pada semester genap tahun ajaran 2015/2016, di bulan April 2016.

Penelitian dilakukan dengan menggunakan metode penelitian eksperimen semu (Quasi Eksperiment). Desain penelitian yang digunakan adalah Posttest-Only Control Group yaitu sebagai berikut (Sugiyono, 2012: 76) :

\section{Tabel 1. Desain Penelitian}

Keterangan:

\begin{tabular}{|c|c|c|}
\hline $\mathrm{R}$ & $\mathrm{X}$ & $\mathrm{O}_{2}$ \\
\hline $\mathrm{R}$ & & $\mathrm{O}_{4}$ \\
\hline
\end{tabular}

$\mathrm{R} \quad$ : Terdapat 2 kelompok yang masing-masing dipilih secara random

$\mathrm{O}_{2}$ : Kelompok Eksperimen

$\mathrm{O}_{4} \quad$ : Kelompok Kontrol

$\mathrm{X}$ : Perlakuan pada kelompok eksperimen berupa penerapan model pembelajaran Quantum Teaching tipe TANDUR diintegrasikan dengan kartu tangram terhadap hasil belajar matematika siswa

Dalam penelitian ini ada 2 variabel, yaitu :

i. Variabel Model Pembelajaran Quantum Teaching tipe TANDUR diintegrasikan dengan kartu tangram $(\mathrm{X})$ 
Populasi dalam penelitian ini adalah seluruh siswa SMPIT Ulil Albab kelas 7 semester genap yang berjumlah 4 kelas tahun ajaran 2015-2016 dengan jumlah siswa sebanyak 120 siswa. Sampel yang diambil dalam penelitian ini adalah siswa kelas 7 Shafiyyah dan kelas 7 Ali. Pada penelitian ini teknik pengambilan sampel yang digunakan adalah purposive sampling dan simple random sampling. Purposive sampling dikenal juga dengan sampling pertimbangan ialah teknik sampling yang digunakan peneliti jika peneliti mempunyai pertimbangan-pertimbangan tertentu di dalam pengambilan sampelnya atau penentuan sampel untuk tujuan tertentu (Riduwan, 2015: 63). Dalam hal ini pemilihan kelas dilakukan terlebih dahulu dengan mewawancarai guru matematika kelas 7 terlebih dahulu, dari wawancara tersebut diperoleh data yang menunjukkan kelas dengan kreativitas belajar matematika siswa terendah. Sedangkan simple random sampling ialah cara pengambilan sampel dari anggota populasi dengan menggunakan acak tanpa memperhatikan strata (tingkatan) dalam anggota populasi tersebut (Riduwan, 2015: 58). Dalam hal ini 2 kelas yang sudah dipilih melalui wawancara tersebut akan dijadikan objek penelitian.

Dalam penarikan sampel maka jumlahnya harus representative agar hasilnya bisa digeneralisasikan. Untuk memenuhi persyaratan tersebut maka dalam menentukan jumlah sampel, peneliti menggunakan rumus perhitungan Taro Yamane (Riduwan, 2015: 65). Dalam penelitian ini, peneliti menggunakan dua macam instrumen yaitu : tes dan wawancara.

Dalam analisa data dilakukan beberapa tahapan yang meliputi :

a. Uji Normalitas

Langkah-langkah yang digunakan dalam pengujian ini menggunakan uji Liliefors

b. Uji Homogenitas

Langkah-langkah yang digunakan dalam pengujian ini menggunakan uji Fisher

c. Uji Hipotesis

Setelah melakukan uji normalitas dan uji homogenitas, maka langkah berikutnya adalah melakukan analisis uji-t. Adapun hipotesis statistik yang digunakan dalam penelitian ini adalah :

$$
\begin{aligned}
& \mathrm{H}_{0}: \mu_{1} \leq \mu_{2} \\
& \mathrm{H}_{1}: \mu_{1}>\mu_{2}
\end{aligned}
$$

Keterangan:

$H_{0}$ : Rata-rata hasil belajar matematika siswa yang tidak menggunakan model pembelajaran Quantum Teaching tipe TANDUR diintegrasikan dengan kartu tangram tidak lebih tinggi dibandingkan dengan menggunakan model 
pembelajaran Quantum Teaching tipe TANDUR diintegrasikan dengan kartu tangram

$H_{1}$ : Rata-rata hasil belajar matematika siswa yang menggunakan model pembelajaran Quantum Teaching tipe TANDUR diintegrasikan dengan kartu tangram lebih tinggi dibandingkan dengan tidak menggunakan model pembelajaran Quantum Teaching tipe TANDUR diintegrasikan dengan kartu tangram

$\mu_{1}$ : Rata-rata hasil belajar matematika siswa yang menggunakan model pembelajaran Quantum Teaching tipe TANDUR diintegrasikan dengan kartu tangram

$\mu_{2}$ : Rata-rata hasil belajar matematika siswa yang tidak menggunakan model pembelajaran Quantum Teaching tipe TANDUR diintegrasikan dengan kartu tangram

\section{HASIL DAN PEMBAHASAN}

Penelitian ini menggunakan kelas 7 sebagai populasi. Penelitian dimulai dari melakukan wawancara dengan guru matematika di sekolah tersebut untuk memperoleh informasi tentang kelas yang kemampuan hasil belajar matematikanya rendah. Berdasarkan wawancara yang telah peneliti lakukan pada hari Kamis tanggal 28 April 2016 maka diperoleh kesimpulan bahwa dari 4 kelas yang ada, kelas 7 Ali dan kelas 7 kelas Shaffiyah adalah kelas yang memiliki hasil belajar matematika terendah. Setelah itu, peneliti memilih kelas 7 Ali yang akan dijadikan kelas kontrol dan kelas 7 Shaffiyah yang akan dijadikan kelas eksperimen.

Proses penelitian dilanjutkan dengan merancang perangkat pembelajaran yang digunakan dalam penelitian. Perangkat pembelajaran yang dibuat berupa : (1) RPP kelas kontrol dan eksperimen, (2) kisi-kisi soal tes hasil belajar matematika, (3) soal tes hasil belajar matematika. Sebelum perangkat pembelajaran digunakan, perangkat pembelajaran divalidasi para ahli.

Setelah perangkat-perangkat pembelajaran divalidasi oleh para ahli dan dilakukan revisi sesuai saran dan komentar para ahli, perangkat pembelajaran diuji cobakan kepada siswa. Perangkat pebelajaran yang diuji cobakan adalah soa-soal tes hasil belajar matematika. Uji coba dilakukan untuk mendapatkan perangkat pembelajaran yang lebih baik. Hasil uji coba dianalisis dengan uji validitas dan uji reliabilitas. Hasil analisis dikonsultasikan kembali kepada para ahli. Sehingga diperoleh perangkat pembelajaran yang siap digunakan. 
Materi pembelajaran yang diterapkan adalah segitiga yang meliputi : mengidentifikasi sifat-sifat segitiga berdasarkan sisi dan sudutnya, menghitung keliling dan luas bangun segitiga dan serta menggunakannya dalam pemecahan masalah dan melukis segitiga, garis tinggi, garis bagi, garis berat dan garis sumbu.

Proses pembelajaran dilaksanakan tanggal 2 Mei 2016 sampai dengan 20 Mei 2016. Pelaksanaan pembelajaran pada siswa kelas kontrol dan eksperimen masing-masing dilaksanakan 5 kali pertemuan. Pada pertemuan pertama, baik di kelas kontrol maupun kelas eksperimen, 10 menit pertama digunakan sebagai perkenalan dan 60 menit selanjutnya untuk menyampaikan materi. Pembelajaran di kelas kontrol tidak menerapkan model pembelajaran Quantum Teaching tipe TANDUR diintegrasikan dengan kartu tangram, sedangkan di kelas eksperimen menerapkan model pembelajaran Quantum Teaching tipe TANDUR diintegrasikan dengan kartu tangram, dimana setiap pertemuan terdiri dari 2 x 35 menit. Pertemuan terakhir, peneliti membagikan soa-soal tes hasil belajar matematika dan melakukan wawancara kepada beberapa siswa. Tes dan wawancara digunakan untuk mengetahui kemampuan hasil belajar matematika siswa dan respon siswa terhadap model pembelajaran Quantum Teaching tipe TANDUR diintegrasikan dengan kartu tangram.

Penelitian dilanjutkan dengan menganalisis atau mengolah data yang telah dikumpulkan dengan metode-metode yang telah ditentukan. Hasil analisis digunakan untuk menjawab hipotesis-hipotesis dalam penelitian dan menarik kesimpulan.

Berikut ini akan disajikan data hasil penelitian berupa hasil tes belajar matematika siswa kelas kontrol dan eksperimen dan hasil wawancara dengan beberapa siswa.

a. Hasil skor tes hasil belajar matematika siswa di kelas kontrol

Dari hasil tes yang telah dibagikan kepada siswa kelas 7 Ali yang tidak diberi perlakuan, maka diperoleh skor yang bervariasi antara 49 sampai 81 dengan rentang skor 32; mean 64,73; median 67; modus 68; simpangan baku 8,82; dan varians 77,72. Untuk lebih jelasnya, data hasil belajar matematika siswa disajikan dalam bentuk tabel distribusi frekuensi sebagai berikut:

Tabel 2. Distribusi Frekuensi Kelas Kontrol

\begin{tabular}{|c|c|c|c|c|c|c|c|}
\hline No & \multicolumn{3}{|c|}{ Interval } & $\overline{\mathbf{X i}}$ & $\mathbf{f}$ & f Rel & f Kum \\
\hline 1 & 49 & - & 54 & 51,5 & 4 & 15 & 15 \\
\hline 2 & 55 & - & 60 & 57,7 & 6 & 23 & 38 \\
\hline 3 & 61 & - & 66 & 63,5 & 3 & 12 & 50 \\
\hline 4 & 67 & - & 72 & 69,5 & 9 & 35 & 85 \\
\hline 5 & 73 & - & 78 & 75,5 & 2 & 8 & 92 \\
\hline 6 & 79 & - & 84 & 81,5 & 2 & 8 & 100 \\
\hline \multicolumn{5}{|c|}{ Jumlah } & 26 & 100 & \\
\hline
\end{tabular}


Distribusi frekuensi kelas kontrol tersebut dapat digambarkan dalam grafik histogram sebagai berikut :

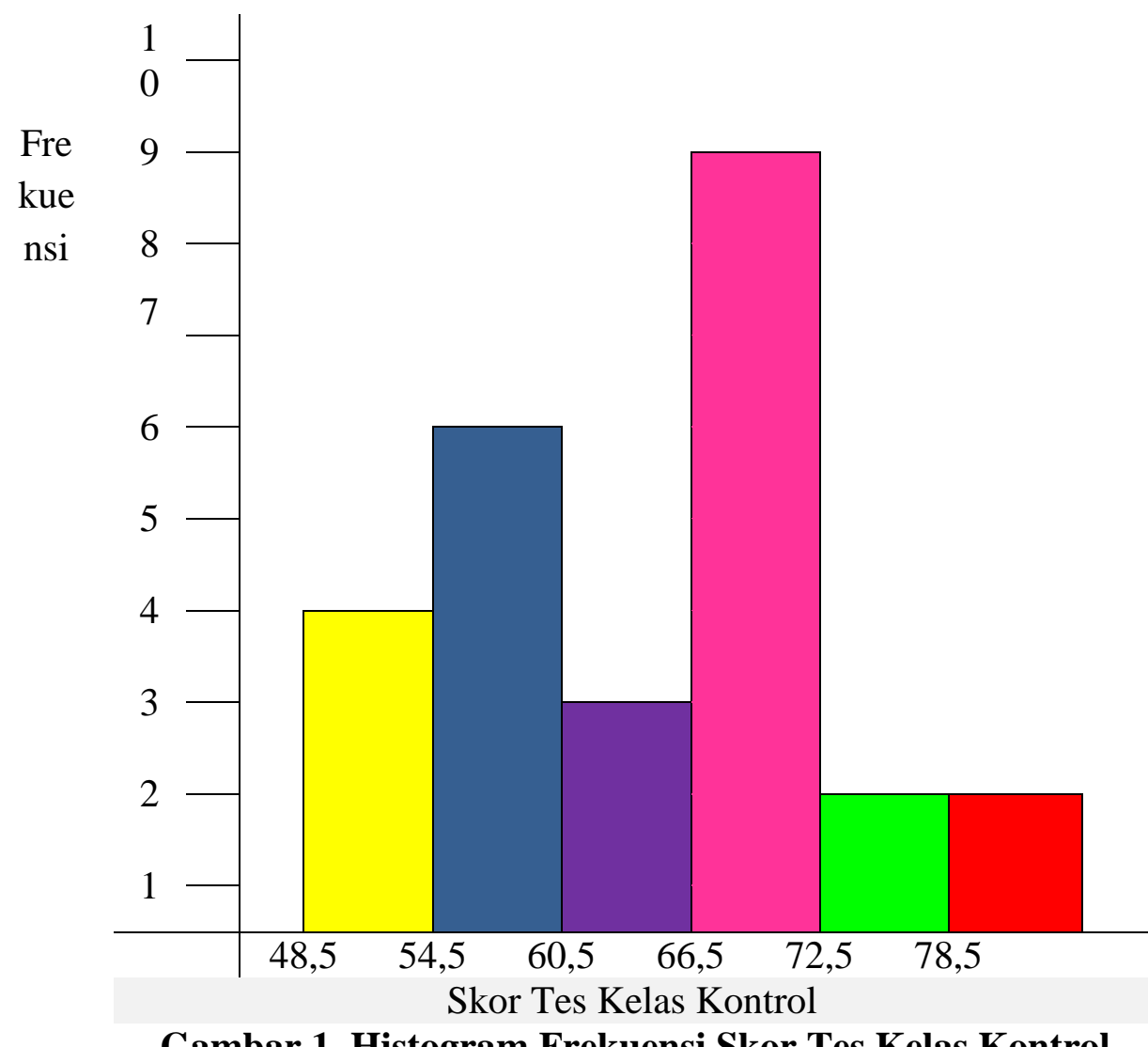

b. Hasil skor tes hasil belajar matematika siswa di kelas eksperimen

Dari hasil tes yang telah dibagikan kepada siswa kelas 7 Shaffiyah yang diberi perlakuan, maka diperoleh skor yang bervariasi antara 69 sampai 90 dengan rentang skor 21; mean 76,96; median 75; modus 70; simpangan baku 6,88; dan varians 47,37. Untuk lebih jelasnya, data hasil belajar matematika siswa disajikan dalam bentuk tabel distribusi frekuensi sebagai berikut :

Tabel 3: Distribusi Frekuensi Kelas Eksperimen

\begin{tabular}{|c|c|c|c|c|c|c|c|}
\hline No & \multicolumn{3}{|c|}{ Interval } & $\mathbf{X i}$ & f & f Rel & f Kum \\
\hline 1 & 69 & - & 72 & 70,5 & 9 & 32 & 32 \\
\hline 2 & 73 & - & 76 & 74,5 & 9 & 32 & 64 \\
\hline 3 & 77 & - & 80 & 78,5 & 1 & 4 & 68 \\
\hline 4 & 81 & - & 84 & 82,5 & 1 & 4 & 71 \\
\hline 5 & 85 & - & 88 & 86,5 & 7 & 25 & 96 \\
\hline 6 & 89 & - & 92 & 90,5 & 1 & 4 & 100 \\
\hline \multicolumn{5}{|c|}{ Jumlah } & 28 & 100 & \\
\hline
\end{tabular}


Distribusi frekuensi kelas eksperimen tersebut dapat digambarkan dalam grafik histogram sebagai berikut :

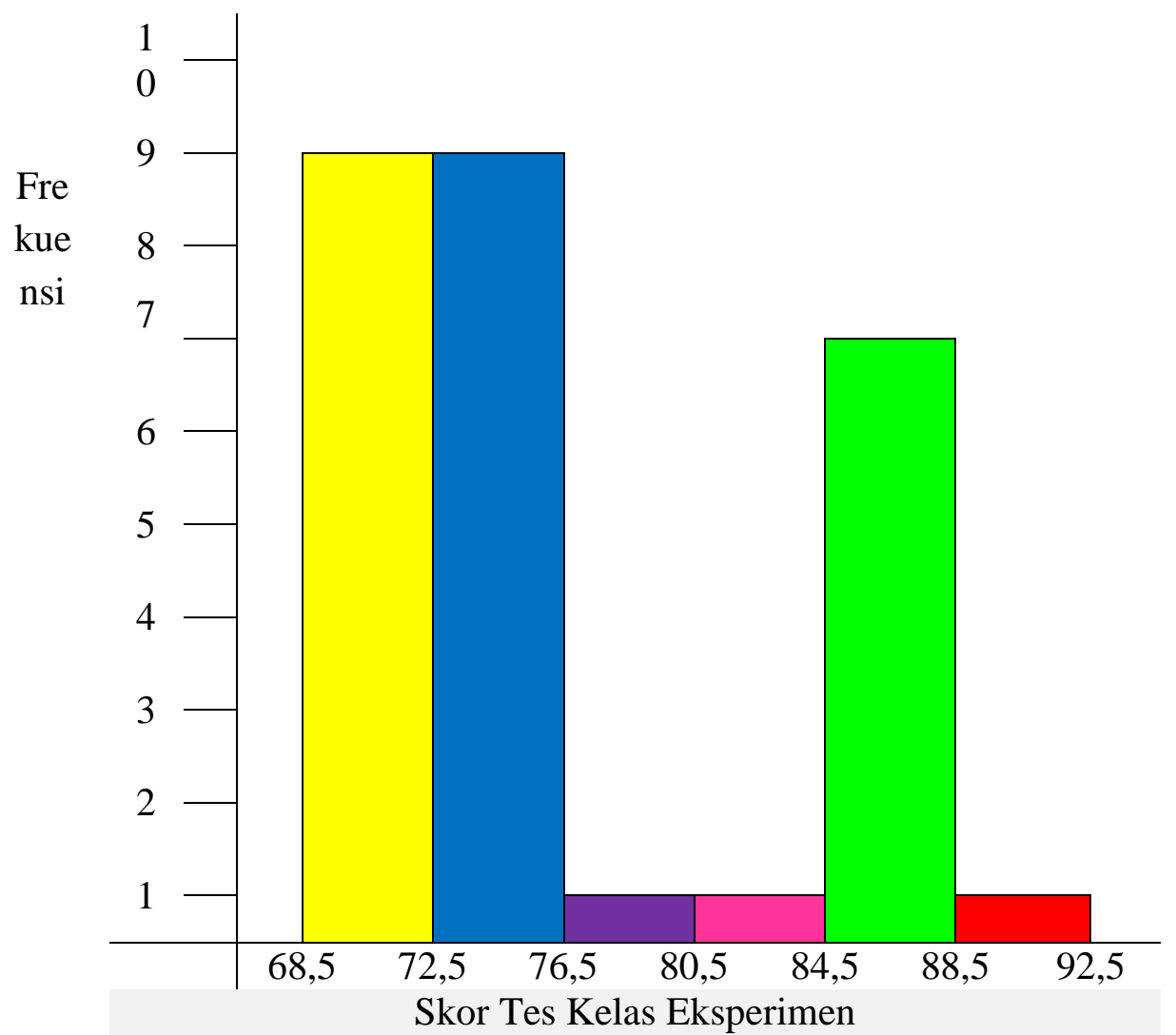

Gambar 2. Histogram Frekuensi Skor Tes Kelas Eksperimen

Berdasarkan uraian mengenai hasil tes belajar matematika siswa di atas, terlihat adanya perbedaan. Untuk lebih memperjelas perbedaan hasil belajar matematika siswa antara kelas kontrol dan eksperimen, dapat dilihat pada tabel berikut :

Tabel 4. Perbandingan Hasil Kelas Kontrol dan Kelas Eksperimen

\begin{tabular}{|c|c|c|}
\hline \multirow{2}{*}{ Statistik } & \multicolumn{2}{|c|}{ Hasil } \\
\cline { 2 - 3 } & Kelas Kontrol & Kelas Eksperimen \\
\hline Skor Terendah & 49 & 69 \\
\hline Skor Tertinggi & 81 & 90 \\
\hline Mean & 64,73 & 76,96 \\
\hline Median & 67 & 75 \\
\hline Modus & 68 & 70 \\
\hline Simpangan Baku & 8,82 & 6,88 \\
\hline Varians & 77,72 & 47,37 \\
\hline
\end{tabular}

Berdasarkan perbandingan data statistik hasil kelas kontrol dan eksperimen pada tabel di atas, dapat dilihat bahwa hasil belajar matematika siswa lebih tinggi dengan diterapkannya model pembelajaran Quantum Teaching tipe TANDUR diintegrasikan dengan kartu tangram. 


\section{c. Hasil Wawancara}

Wawancara dilaksanakan pada hari Jumat, 20 Mei 2016 saat istirahat ke-2 yaitu pukul 12.00. Peneliti melakukan wawancara dengan 2 orang di kelas eksperimen sebagai perwakilan untuk memberikan respon terhadap diterapkannya model pembelajaran Quantum Teaching tipe TANDUR diintegrasikan dengan kartu tangram. Kedua siswa tersebut adalah siswa dengan kode QN dan LR.

Berdasarkan hasil wawancara dengan kedua siswa yang dilakukan oleh peneliti dapat disimpulkan bahwa siswa merasa senang dengan diterapkannya model pembelajaran Quantum Teaching tipe TANDUR diintegrasikan dengan kartu tangram dalam pembelajaran matematika, karena mereka dengan mudah dapat mengerti dan memahami materi, ide-ide kreatif mereka dalam menjawab soal pun lebih berkembang lagi. Selain itu, mereka juga senang karena proses pembelajaran menjadi tidak menjenuhkan, tidak membosankan, dan menjadi semangat belajar karena setiap prestasi yang mereka raih akan ada rewardnya.

\section{SIMPULAN DAN SARAN}

Berdasarkan hasil penelitian dan pembahasan dapat diambil kesimpulan implementasi model pembelajaran Quantum Teaching tipe TANDUR diintegrasikan dengan kartu tangram untuk meningkatkan hasil belajar matematika siswa kelas 7 SMPIT Ulil Albab pada materi segitiga menghasilkan hal-hal sebagai berikut :

1. Hasil belajar matematika siswa pada kelas yang menggunakan model pembelajaran Quantum Teaching tipe TANDUR diintegrasikan dengan kartu tangram meningkat. Hal ini dapat dilihat dari hasil rata-rata skor tes hasil belajar matematika siswa yang diterapkan model pembelajaran Quantum Teaching tipe TANDUR diintegrasikan dengan kartu tangram adalah 76,96. Sedangkan hasil rata-rata skor tes hasil belajar matematika siswa yang tidak diterapkan model pembelajaran Quantum Teaching tipe TANDUR diintegrasikan dengan kartu tangram adalah 64,73. Dan juga berdasarkan analisis data menggunakan uji-t, diketahui $\mathrm{t}_{\text {hitung }}=5,54$ dan $\mathrm{t}_{\text {tabel }}(\mathrm{dk}=52$ pada taraf signifikan 0,05$)=1,67$. Hasil perhitungan tersebut menunjukkan bahwa $t_{\text {hitung }}$ lebih besar daripada $t_{\text {tabel }}\left(t_{\text {hitung }}>t_{\text {tabel }}\right)$, sehingga hasil penelitian adalah terdapat pengaruh yang signifikan.

2. Model pembelajaran Quantum Teaching tipe TANDUR diintegrasikan dengan kartu tangram berpengaruh positif terhadap siswa. Hal ini berdasarkan wawancara yang 
telah dilakukan peniliti. Setelah diterapkannya model pembelajaran tersebut siswa merasa lebih mudah memahami dan mengerti materi dan ide-ide kreatif dalam menyelesaikan soal lebih berkembang. Siswa juga merasa senang karena pembelajaran tersebut menjadi lebih menyenangkan, tidak membosankan dan setiap prestasi yang mereka raih akan mendapatkan reward.

Berdasarkan penelitian yang telah dilakukan, peneliti memberikan beberapa saran sebagai berikut:

1 Pembelajaran dengan model pembelajaran Quantum Teaching tipe TANDUR dintegrasikan dengan kartu tangram hendaknya menjadi salah satu alternatif pembelajaran di kelas, terutama untuk meningkatkan hasil belajar matematika siswa.

2 Pada penelitian ini, hanya mengkaji hasil belajar matematika selanjutnya dapat dilakukan penelitian lanjutan untuk melihat pengaruh model pembelajaran Quantum Teaching tipe TANDUR dintegrasikan dengan kartu tangram terhadap hasil belajar yang berbeda.

\section{DAFTAR PUSTAKA}

Ahmadi, Iif Khoiru. (2014). Pengembangan dan Model Pembelajaran Tematik Integratif. Jakarta: Prestasi Pustakaraya.

Anjasari, Meisa Dwi. (2013). "Meningkatkan Hasil Belajar Materi Mengidentifikasi SifatSifat Bangun Datar Menggunakan Media Tangram Di Sekolah Dasar”. JPGSD. Vol 01 No 02.

Arikunto, Suharsimi. (2013). Prosedur Penelitian Suatu Pendekatan Praktik. Jakarta: Rineka Cipta.

DePorter dkk. (2014). Quantum Teaching: Mempraktikkan Quantum Learning di RuangRuang Kelas. Bandung: Kaifa.

Dwi, Susanto dkk. (2007). Matematika untuk SMP dan MTS kelas VII. Jakarta: PT Grasindo.

Hamzah, Ali. (2014). Perencanaan dan Strategi Pembelajaran Matematika. Jakarta: Rajawali Pers.

Heruman. (2007). Model Pembelajaran Matematika di Sekolah Dasar. Bandung: PT Remaja Rosdakarya.

Kadir. (2015). Statistika Terapan: Konsep, Contoh dan Analisis Data dengan Program SPSS/Lisrel dalam Penelitian. Jakarta: Rajawali Pers.

Kosasih, Nandang. (2013). Pembelajaran Quantum dan Optimalisasi Kecerdasan. Bandung: Alfabeta. 
Murtafi'ah, Umi. (2012). "Penerapan Strategi Pembelajaran Quantum Teaching sebagai Upaya Meningkatkan Keaktifan Belajar Matematika Konsep Pecahan pada siswa kelas IV SD Negeri Bangkok Kecamatan Karanggede Kabupaten Boyolali tahun pelajaran 2012/2013". Skripsi Program Studi Pendidikan Guru Sekolah Dasar Universitas Muhammadiyah Surakarta (naskah diplubikasikan).

Riduwan. (2015). Belajar Mudah Penelitian untuk Guru-Karyawan dan Peneliti Pemula. Bandung: Alfabeta.

Siew, Nyet Moi dan Sopiah Abdullah. (2012). British Journal of Education, Society \& Behavioural Science 2(3): 239-259.

Slameto. (2010). Belajar dan Faktor-Faktor yang mempengaruhi. Jakarta: Rineka Cipta.

SMPIT Ulil Albab. (2016). Silabus Pembelajaran SMPIT Ulil Albab tahun pelajaran 20152016. Cibitung: SMPIT Ulil Albab.

Sugiyono. (2012). Metode Penelitian Kuantitatif Kualitatif dan $R \& D$. Bandung: Alfabeta.

Sujarweni, V. Wiratna. (2015). Statistik Untuk Bisnis dan Ekonomi. Yogyakarta: Pustaka Baru Press.

Suprijono, Agus. (2016). Model-Model Pembelajaran Emansipatoris. Yogyakarta: Pustaka Pelajar.

Susanto, Ahmad. (2013). Teori Belajar dan Pembelajaran. Jakarta: KENCANA.

Uno, Hamzah B. (2009). Mengelola Kecerdasan dalam Pembelajaran. Jakarta: Bumi Aksara.

Wasrie, Moh. Kusnadi. (2015). Buku Pintar Matematika. Jakarta: Lingkar Media.

Wishnu, Pande dkk. (2014). "Penerapan Model Pembelajaran Explicit Instruction Berbantuan Media Konkret untuk Meningkatkan Hasil Belajar IPA Siswa Kelas VI SDN 17 Dangin Puri Kota Denpasar”. Jurnal Mimbar PGSD Universitas Pendidikan Ganesha Jurusan $P G S D$. Vol 2 No 1.

\section{UCAPAN TERIMAKASIH}

Ucapan terima kasih kami sampaikan kepada Direktorat Jenderal Pendidikan Tinggi (Dirjen DIKTI) yang telah membiayai sepenuhnya penelitian ini dalam Program Kreatifitas Mahasiswa (PKM) dalam Skema Penelitian tahun 2015. 